\title{
DETERMINAN DEFORESTASI NEGARA-NEGARA DI KAWASAN ASIA TENGGARA PERIODE 2008-2015
}

\section{DETERMINANT OF DEFORESTATION IN SOUTHEAST ASIA OF THE 2008-2015 PERIOD}

\author{
Radite Teguh Handalani \\ BPSDM Provinsi DKI Jakarta, Gedung Dinas Teknis, Jl. Abdul Muis no. 66; Jakarta Pusat, Indonesia; \\ raditehandalani12@gmail.com
}

Info Artikel:

- Artikel Masuk: 30 November 2018

\begin{abstract}
ABSTRAK
Penelitian ini bertujuan menganalisis proses perubahan luas area hutan atau deforestasi yang bersifat multidimensional dan kompleks, mencakup aspek ekonomi, aspek tata kelola pemerintahan, aspek sosial dan demografi serta aspek fisik dan lingkungan yang diwakili oleh 15 variabel independen di 10 negara di Asia Tenggara pada periode tahun 2008-2015. Analisis dan kajian tersebut selain bersandar pada landasan teori dan penelitian terdahulu juga memasukan beberapa variabel yang menggambarkan kompleksitas dan multidimensinya perubahan luas areal hutan. Namun, upaya tersebut seringkali terkendala oleh ketidaklengkapan data dan keandalan data. Berbeda dengan beberapa penelitian terdahulu yang lebih memfokuskan aspek ekonomi atau aspek penambahan jumlah penduduk yang mempengaruhi perubahan luas area hutan. Penelitian ini juga memasukan aspek tata kelola pemerintahan dan aspek sosial dan kependudukan serta fisik-lingkungan yang diharapkan dapat melengkapi spektrum dan kajian terhadap masalah deforestasi dan degradasi hutan. Metode yang digunakan dalam penelitian ini menggunakan analisis regresi data panel (pooled least squares) dan serangkaian pengujian untuk menghasilkan spesifikasi model dan estimator terbaik. Dalam penelitian yang menggunakan tingkat keyakinan sebesar $95 \%$ pada p-value pada nilai $\alpha=0,05$ ditemukan bahwa dari 15 variabel hanya terdapat 6 (enam) variabel yang berpengaruh signifikan terhadap peningkatan indeks pembangunan manusia.
\end{abstract}

Kata kunci: deforestasi, tata kelola pemerintahan , pembangunan berkelanjutan.

\begin{abstract}
This study aims to analyze the process of changing forest area or deforestation that is multidimensional and complex, encompassing economic aspects, aspects of governance, social and demographic aspects and physical and environmental aspects represented by 15 independent variables in 10 countries in Southeast Asia in the year period 2008-2015. The analysis and study besides relying on the theoretical foundation and previous research also included several variables that describe the complexity and multidimensional changes in forest area. However, these efforts are often constrained by incomplete data and data reliability. In contrast to some previous studies which focused more on economic aspects or aspects of population increase that affected changes in forest area. This research also includes aspects of governance and social and demographic aspects as well as environmental aspect which are expected to complement the spectrum and study of the problems of deforestation and forest degradation. The method used in this study uses pooled least squares and a series of tests to produce the best model specifications and estimators. In research that uses a $95 \%$ confidence level on p-value at a value of $\alpha=0.05$, it was found that from 15 variables there were only 6 (six) variables that significantly affected the increase in the human development index.
\end{abstract}

Keywords: deforestation, governance, sustainable development. 


\section{PENDAHULUAN}

Pembangunan sebagai suatu proses sadar dan terencana menjadi salah satu fungsi dan tujuan dibentuknya sebuah pemerintahan di setiap negara. Tujuan pembangunan tersebut pada hakekatnya diarahkan untuk meningkatkan derajat, kualitas hidup dan kesejahteraan masyarakatnya. Untuk memenuhi tujuan tersebut dalam proses pembangunan, pemerintahan menyelenggarakan segenap kebijakan, program dan kegiatan yang selanjutnya tercermin dalam anggaran. Dalam perkembangannya saat ini paradigma pembangunan telah sampai pada konsep pembangunan berkelanjutan (sustainable development) dan konsep mekanisme pembangunan bersih/hijau (clean development mechanism). Lebih jauh, secara khusus dalam upaya menanggulangi polusi akibat emisi, salah satunya gas karbon yang dimulai melalui the United Nations Framework Convention on Climate Change (UNFCCC), kesepakatan sebagaimana tercantum dalam Protokol Kyoto (1997 dan 2005) serta REDD+ (Reducing Emissions from Deforestation and forest Degradation) dalam (James Baker, 2014) menghasilkan komitmen untuk mengurangi dampak emisi dan penggundulan hutan (deforestation) sebagai dampak dari pembangunan. Namun, tidak dapat dipungkiri bahwa pembangunan baik aspek fisik maupun ekonomi juga memiliki dampak terhadap keberlangsungan lingkungan, salah satunya hutan. Dalam kenyataannya, proses pembangunan di berbagai negara sebagai upaya untuk meningkatkan kesejahteraan masyarakat, di sisi lain justru berdampak pada berkurangnya luas areal hutan. Hal tersebut sebagaimana terjadi di Indonesia salah satunya di wilayah Sumatera yang mengalami proses deforestasi tercepat sebagaimana temuan (Margono, et al., 2012). Temuan yang sama juga terjadi di hutan hujan tropis dan bantaran sungai Amazon di wilayah Brazil dan Bolivia (Song X-P, Huang, Saatchi, Hansen, \& Townshend, 2015).

Berkaitan dengan dampak pembangunan berupa meningkatnya emisi karbon dan polutan, berkurangnya areal hutan dan lahan pertanian serta berkurangnya kualitas lingkungan yang terjadi di berbagai daerah dan negara banyak menjadi fokus penelitian para peneliti dan pemerhati lingkungan. Salah satu temuan terbaru sebagaimana dinyatakan (Rudel, 2013) bahwa terdapat perbedaan penyebab deforestasi yang terjadi di kawasan Afrika dengan deforestasi yang terjadi di kawasan Asia dan Amerika Latin. Di Asia dan Amerika latin pesatnya penggundulan dan degradasi hutan cenderung lebih disebabkan oleh pembukaan lahan pertanian, perkebunan dan peternakan dalam skala besar. Namun, sebaliknya di Afrika khususnya wilayah Congo dan Kinshasa deforestasi lebih disebabkan oleh kemiskinan dan kebutuhan areal pertanian dalam skala kecil untuk pemenuhan kebutuhan pangan. Dari temuan tersebut dapat disimpulkan bahwa pembukaan areal pertanian, faktor kemiskinan dan konsumsi dapat menjadi pendorong masyarakat untuk secara langsung maupun tidak langsung membuka dan menggunduli areal hutan.

Dalam perspektif yang berbeda, banyak peneliti melakukan kajian terhadap variabel determinan terhadap deforestasi salah satunya aspek ekonomi. Meningkatnya laju pembangunan dan pertumbuhan ekonomi akan mendorong manusia untuk semakin meningkatkan kualitas hidup dan konsumsinya sebagaimana banyak diyakini oleh para ahli perencanaan pembangunan dan ekonomi (Mankiw, 2009), (Jinghan, 2007) dan (Todaro \& Smith, 2006). Upaya pemenuhan kebutuhan hidup tersebut pada akhirnya akan mendorong semakin besarnya kebutuhan akan penguasan lahan dan sumber-sumber ekonomi baik untuk areal permukiman maupun sumber daya ekonomi lainnya seperti lahan pertanian, perkebunan, peternakan dan pertambangan yang pada akhirnya juga turut mendorong berkurangnya areal hutan. Hal tersebut sebagaimana kajian dan temuan (Houghton, et al., 2012) yang menyimpulkan bahwa motif 
ekonomi untuk membuka areal pertanian, perkebunan dan peternakan mendorong terjadinya degradasi dan deforestasi dan pada akhirnya meningkatkan emisi karbon. Dalam temuan yang berbeda (Goncalves da Silva \& Krisztina, 2010) justru menemukan fakta bahwa pendorong meningkatnya deforestasi di Amazon, Brazil adalah harga daging dan kacang kedelai sebagai penyebab terbesar selain variabel dalam aspek politik yaitu kredit perdesaan dan denda kerusakan lingkungan yang kurang efektif. Peneliti lainnya yang memfokuskan kajian pada hubungan aspek pembangunan ekonomi dengan deforestasi juga dilakukan oleh (Cuaresma, et al., 2016) yang menemukan bukti yang kuat berupa konsep pembangunan ekonomi sebagaimana dijelaskan dalam Kurva Kuznets sebagai penyebab utama deforestasi melalui angka GDP Percapita.

Beberapa penelitian lebih menitikberatkan kajian berupa pembukaan areal hutan dan deforestasi akibat variabel kependudukan (demografi). Banyak ahli yang menemukan keterkaitan meningkatnya angka populasi dengan semakin berkurangnya areal hutan didorong motif kebutuhan akan lahan permukiman. Penelitian (Dariono, Siregar, \& Nofrizal, 2018), (Sunderlin \& Resosudarmo, 1996), (Carr, 2009) serta (Liu, 2013) dan (Samsuri, Jaya, Kusmana , \& Murtilaksono, 2014) menunjukan bahwa laju pertumbuhan penduduk menjadi pendorong utama terbukanya areal hutan dan deforestasi. Penelitian lainnya sebagaimana dilakukan (Imai, Furukawa, Tsujino, Kitamura, \& Yumoto, 2018) juga menemukan bahwa faktor kependudukan dan lingkungan menjadi pendorong terbesar terjadinya deforestasi di kawasan Asia Tenggara pada periode 1980-2010. Tidak dapat dipungkiri bahwa kebutuhan akan lahan tempat tinggal, pertanian skala kecil dan perkebunan menjadi salah satu pendorong penduduk membuka areal hutan yang seringkali dilakukan dengan cara membakar hutan. Temuan (Rijal, Jaya, Tiryana, \& Saleh, 2016) juga menemukan variabel penyebab kerusakan areal hutan di kawasan Kampar dan Indragiri Hulu selain pertanian skala kecil dan perkebunan juga disebabkan faktor kebakaran hutan.

Berbeda dengan penelitian-penelitian terdahulu yang melakukan kajian pada aspek ekonomi dan demografi, beberapa peneliti menemukan keterkaitan antara faktor korupsi dalam perizinan dan penggunaan Hak Pengelolaan Hutan dengan deforestasi sebagaimana temuan (Koyuncu \& Yilmaz, 2009) dan (Pachmann, 2018). Berdasarkan hasil penelitian tersebut, korupsi dan desentralisasi yang tidak terkontrol menjadi salah satu penyebab terjadinya deforestasi di berbagai negara (Koyuncu \& Yilmaz, 2009) termasuk Indonesia (Pachmann, 2018). Sejalan dengan temuan tersebut, dapat disimpulkan pula bahwa faktor tata kelola pemerintahan dan kelembagaan (insitusi) menjadi salah satu penyebab terjadinya deforestasi (Cuaresma, et al., 2016). Dalam perspektif lainnya, (Yani, 2016) juga mengaitkan masalah sosial sebagai penyebab terjadinya deforestasi. Salah satu variabel yang digunakan dalam penelitian tersebut adalah Indeks Pembangunan Manusia (Human Development Index) sebagai variabel determinan deforestasi di wilayah Sulawesi Selatan dan Sulawesi Barat. Penggunaan indikator IPM/HDI juga dilandasi konsep bahwa Indeks Pembangunan Manusia (IPM) yang secara kualitatif menggambarkan tingkat kesejahteraan masyarakat sebagaimana kajian (Sen, 1999), (Anand \& Sen, 1997) dan (Ul-Haq, 2003) sangat berkaitan dengan aspek lingkungan salah satunya areal hutan.

Dari berbagai hasil penelitian tersebut dapat disimpulkan bahwa berkurangnya areal hutan akibat deforestasi dan degradasi di berbagai negara merupakan masalah yang kompleks dan multidimensional karena berkaitan dengan beragam aspek. Pesatnya pembangunan ekonomi, fisik dan pertumbuhan penduduk dunia turut memberikan kontribusi pada semakin berkurangya areal hutan, berkurangnya kualitas lingkungan hutan dan semakin tingginya emisi karbon yang mendorong menurunnya kualitas 
Handalani/ Jurnal Pembangunan Wilayah dan Kota, Vol 15, No. 1, 2019, 1-19

Doi: $10.14710 /$ pwk.v15i1.21267

lingkungan. Dalam kenyataannya perubahan luas areal hutan sebagaimana terjadi di kawasan Asia Tenggara, dapat terlihat sebagaimana gambar berikut:

\section{Gambar 1: Perubahan Luas Area Hutan di Kawasan Asia Tenggara}

Periode 2008-2015

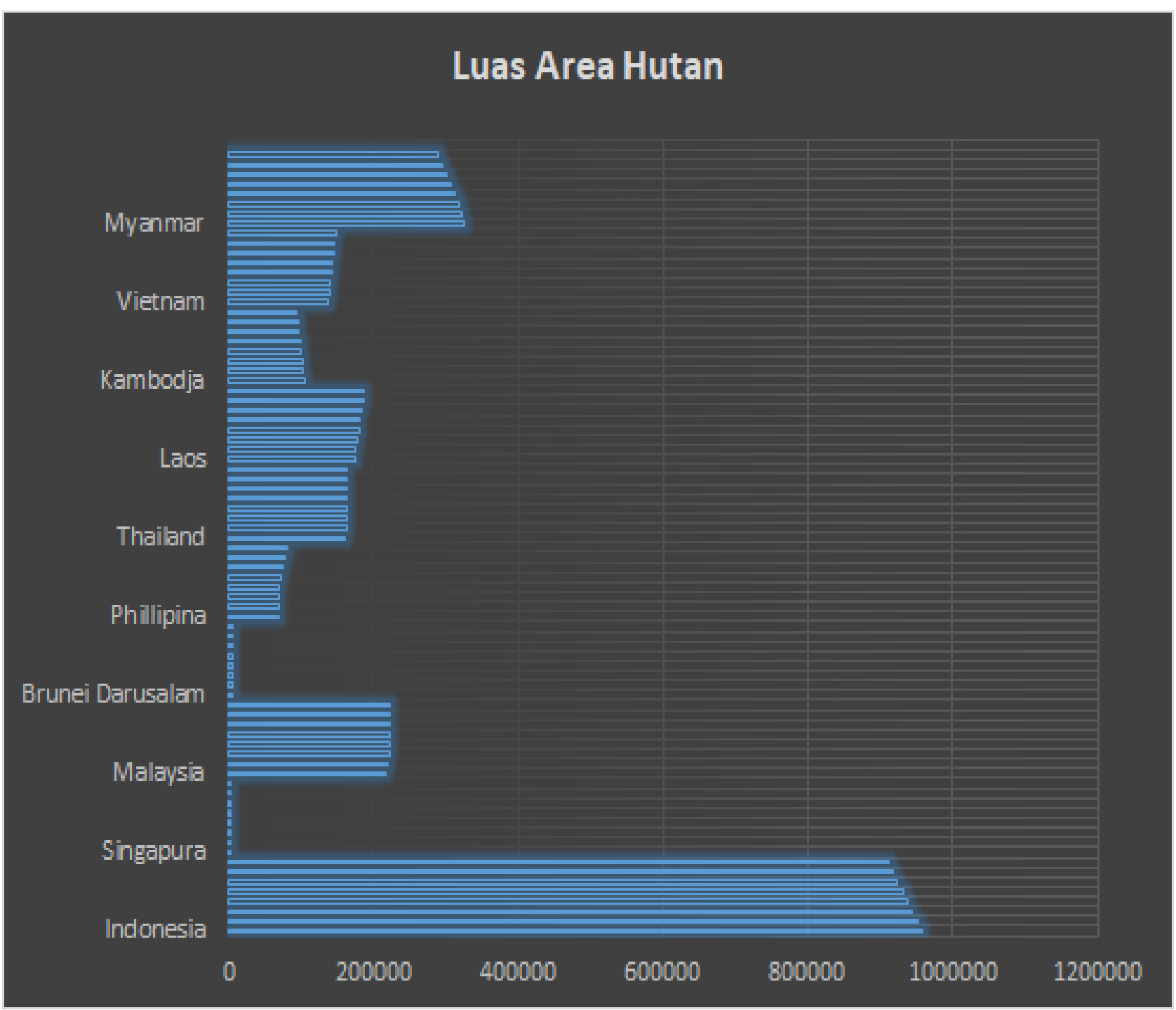

Sumber: $\quad$ Data sekunder Worldbank, UNDP, ADB, Tradingeconomy dan lain-lain diolah.

Dari gambar 1 di atas dapat terlihat bahwa proses degradasi dan deforestasi terjadi di beberapa negara antara lain: Vietnam, Laos, Philipina dan Malaysia. Di sisi lain terjadi perubahan berupa meningkatnya luas area hutan sebagaimana terjadi di negara-negara: Myanmar, Kamboja dan Indonesia. Sedangkan Thailand relative stabil luas area hutannya dan Singapura dan Brunei Darussalam tidak terlalu signifikan karena luas area hutannya relatif kecil. Namun apabila data tersebut disusun dengan menggunakan indikator persentase luas area hutan terhadap luas wilayah serta dibandingkan dengan angka pertumbuhan ekonomi, maka dapat terlihat bahwa perubahan luas area hutan di beberapa negara relative tidak signifikan jika dibandingkan dengan luas wilayah serta keterkaitannya dengan persentase pertumbuhan ekonomi. Hal tersebut menyiratkan pandangan bahwa kerusakan hutan sebagai akibat 
proses pembangunan tidak secara linier mendorong pertumbuhan ekonomi. Namun apabila diteliti lebih jauh dampak dari kerusakan hutan terhadap kualitas lingkungan dan aspek ekonomi yang terkandung di dalamnya seperti polusi akibat emisi karbondioksida maka yang tidak dapat dipungkiri bahwa perubahan area hutan perlu menjadi focus perhatian para perencana pembangunan. Hubungan tersebut dapat dilihat sebagaimana gambar 2 berikut:

Gambar 2: Perubahan \% Area Hutan terhadap Wilayah Negara-negara

di Kawasan Asia Tenggara

Periode 2008-2015

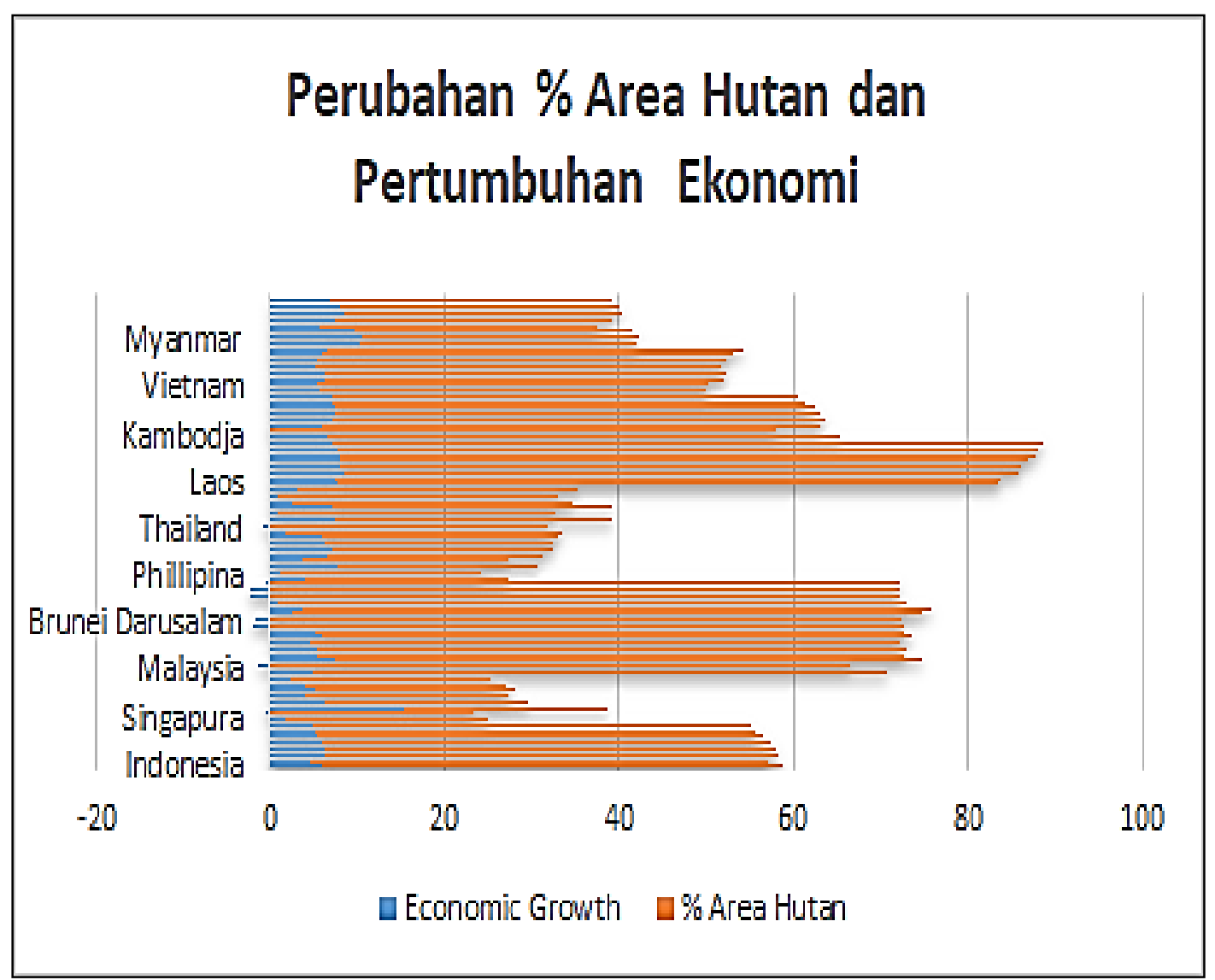

Sumber: $\quad$ Data sekunder Worldbank, UNDP, ADB, Tradingeconomy dan lain-lain diolah.

Tumbuhnya kesadaran akan pentingnya upaya menjaga kelestarian lingkungan termasuk di dalamnya kelestarian hutan bagi kehidupan yang bersifat kompleks dan multidimensional, maka upaya untuk mengkajinya juga memerlukan upaya yang besar dan seksama. Untuk itu, penelitian ini selain sebagai bentuk kajian terhadap perubahan luas area hutan di kawasan Asia Tenggara juga dimaksudkan untuk melakukan kajian terhadap variabel-variabel determinannya. Selain mengaitkan aspek ekonomi sebagai salah satu variabel penentu perubahan luas area hutan yang mengandung potensi degradasi dan deforestasi di Asia Tenggara, penelitian ini juga mengaitkannya dengan aspek tata kelola pemerintahan, sosial dan kependudukan serta aspek fisik penggunaan lahan. Untuk aspek ekonomi variabel yang dikaji dalam penelitian ini sejalan dengan beberapa penelitian terdahulu dikaitkan dengan angka PDB Nominal pada harga konstan, PDB Perkapita, Pertumbuhan ekonomi (Economic Growth), Pendapatan Perkapita, 
Inflasi, dan Investasi (Foreign Direct Investment). Sedikit berbeda dengan penelitian terdahulu, dalam penelitian ini juga dikaitkan faktor inflasi dan investasi karena sebagaimana dijelaskan oleh (Nawir, Murniati, \& Rumboko, 2007) aspek ekonomi memiliki pengaruh tidak langsung yang signifikan terhadap deforestasi. Sedangkan variabel Inflasi dan Investasi (FDI) juga menjadi variabel yang signifikan terhadap pembangunan ekonomi.

Dalam penelitian ini, variabel independen yang berkaitan dengan aspek tata kelola kepemerintahan (governance) diwakili oleh variabel: Efektivitas Pemerintahan (Government Effectiveness), Indeks Persepsi Korupsi (CPI), Keterbukaan dan Akuntabilitas dan Kontrol terhadap Korupsi (COC), Keterbukaan dan Akuntabilitas (Voice and Accountability) serta variabel Ratio Hutang Pemerintah (Government Debt). Adapun aspek sosial dan kependudukan (demografi) diwakili oleh angka: Human Development Index (HDI/IPM), jumlah penduduk dan tingkat pengangguran. Untuk aspek fisik, dengan bersandar pada beberapa temuan penelitian terdahulu sebagaimana (Rudel, 2013), (Margono, et al., 2012), (Houghton, et al., 2012) dan (Rijal, Jaya, Tiryana, \& Saleh, 2016) penelitian ini menggunakan luas area pertanian dan perkebunan sebagai variabel yang turut menentukan perubahan luas area hutan. Upaya untuk melakukan kajian dengan melibatkab berbagai aspek dan spektrum yang mendorong perubahan area hutan serta potensi degradasi dan deforestasi di dalamnya dilandasi pertimbangan bahwa upaya untuk mengkaji secara komprehensif mustahil dapata dilakukan apabula hanya menyandarkan pada aspek ekonomi atau aspek kependudukan semata. Beberapa temuan sebagaimana (Koyuncu \& Yilmaz, 2009) dan (Pachmann, 2018) justru memasukan aspek tata kelola dan institusi. Berbeda dengan penelitian terdahulu dalam penelitian ini tidak hanya menggunakan indikator CPI namun juga melibatkan variabel lain seperti Government Effectiveness, Voice and Accountability, Control of Corruption dan rasio hutang pemerintah terhadap GDP.

Lokus penelitian ini adalah 10 negara di kawasan Asia Tenggara yag tergabung dalam ASEAN. Adapun pertimbangan pemilihan locus tersebut selain disebabkan masalah kelengkapan data juga berkaitan erat dengan ragam bentuk pemerintahan, tingkat kesejahteraan masyarakat, aspek sosial dan budaya serta variasi jumlah penduduk dan luas wilayah. Metode pengolahan dan analisis data dalam penelitian ini menggunakan analisis data panel (pooled data) yang dilandasi beberapa pertimbangan berupa beberapa kelebihan dalam metode dan analisis data panel sebagaimana dijelaskan oleh (Nachrowi \& Usman, 2006), (Gujarati, 1997) dan (Ekananda, 2016). Sebagaimana diyakini oleh para ahli statistika dan ekonometrika, data panel memiliki keunggulan berupa analisis dan penjelasan yang bersifat spesifik untuk melakukan estimasi terhadap masing-masing karakteristik individu maupun waktu secara terpisah dan kelebihan jumlah pengamatan menjadi lebih banyak.

\section{DATA DAN METODE}

Penelitian ini bertujuan untuk melakukan kajian terhadap perubahan luas area hutan negara-negara di kawasan Asia Tenggara dan upaya untuk menemukan variabel-variabel determinannya. Dalam prakteknya, penelitian ini mencoba melakukan analisis terhadap variable-variabel ekonomi, tata kelola kepemerintahan, sosial dan kependudukan serta variabel fisik lingkungan yang diwakili oleh luas area pertanian dan perkebunan serta pengaruhnya terhadap perubahan luas area hutan di kawasan Asia Tenggara menggunakan metode deskriptif-kuantitatif. Selanjutnya data yang telah diperoleh berkaitan dengan variabel-variabel penelitian yang telah ditetapkan dapat digambarkan sebagaimana model dan kerangka berpikir (logical framework), berikut: 
Gambar 3: Logical Framework Determinant of Forestland in South-East Asia

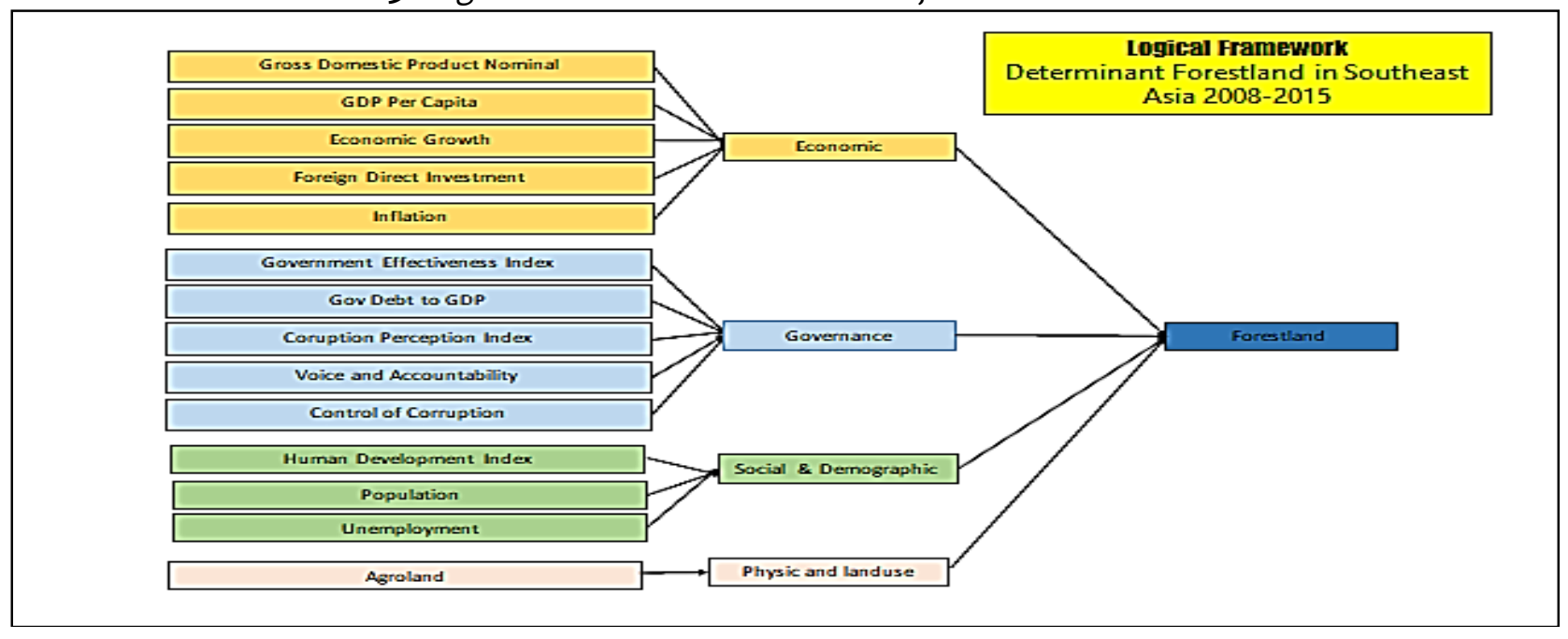

Data yang diolah dan dianalisis dalam penelitian ini merupakan kumpulan data cross-section pada sepuluh negara di Asia Tenggara dan data time-series pada kurun waktu 10 tahun mulai 2008-2015. Data panel (pooled data) tersebut selanjutnya dianalisis dengan menggunakan metode ekonometrik menggunakan aplikasi e-Views 9.0. Data-data yang terdapat dalam penelitian ini sebagian besar dihimpun dari Worldbank, Asian Development Bank (ADB), United Nation Development Programme (UNDP), Transparancy International ( $\mathrm{TI})$, Tradingeconomy, Statista dan sumber-sumber lainnya dan diharapkan dapat menemukan determinan variabel terhadap perubahan luas area hutan. Selanjutnya dalam penelitian ini akan dilakukan analisis regressi data panel dan mencari model yang terbaik berdasarkan metode common pool, fixed effect dan random effect dan dilakukan pemilihan model atau estimator terbaik dengan serangkaian pengujian (test). Adapun hipotesis yang dibangun dalam penelitian ini, sebagai berikut:

$\mathbf{H}_{\mathbf{0}} \quad$ : Tidak ada pengaruh yang signifikan antara variabel GDP, GDP Per Capita, Income Percapita, Pertumbuhan Ekonomi, Foreign Direct Investment, Inflasi, Human Development Index, jumlah penduduk, jumlah pengangguran, Government Effectiveness Index, Rasio Hutang Pemerintah terhadap GDP, Corruption Perception Index (CPI), Voice and Accountability (VA) dan Control of Corruption (CC) serta Luas Area Pertanian dan Perkebunan secara keseluruhan terhadap Perubahan Luas Area Hutan di negara-negara di kawasan Asia Tenggara.

$\mathbf{H}_{1} \quad$ : Ada pengaruh yang signifikan antara variabel GDP, GDP Per Capita, Income Percapita, Pertumbuhan Ekonomi, Foreign Direct Investment, Inflasi, Human Development Index, jumlah penduduk, jumlah pengangguran, Government Effectiveness Index, Rasio Hutang Pemerintah terhadap GDP, Corruption Perception Index (CPI), Voice and Accountability (VA) dan Control of Corruption (CC) serta Luas Area Pertanian dan Perkebunan secara keseluruhan terhadap Perubahan Luas Area Hutan di negara-negara di kawasan Asia Tenggara.

Selanjutnya hipotesis tersebut diuji dengan menggunakan analisis data panel dengan metode regresi berganda (multiple-regression) di negara-negara Asia Tenggara Tahun 2008-2015. Menggunakan aplikasi E-views 9.0 dan ditetapkan tingkat keyakinan sebesar $95 \%$ pada $p$-value pada nilai $\alpha=0,05$ maka dapat ditentukan varaibel-variabel yang signifak mempengaruhi variabel perubahan luas area hutan. Adapun spesifikasi model penelitian ini dapat dituliskan dalam notasi sebagai berikut: 
Handalani/ Jurnal Pembangunan Wilayah dan Kota, Vol 15, No. 1, 2019, 1-19

Doi: $10.14710 /$ pwk.v15i1.21267

$$
y_{i t}=\alpha+\beta_{i t} x_{i t}+\mu_{i t}
$$

Keterangan:

1. $y_{i t} \quad$ adalah observasi dari unit ke-i dan diamati pada periode waktu ke-t.

2. $\alpha_{i t} \quad$ adalah intercept dari unit ke-i pada periode ke-t;

3. $\beta_{i t} \quad$ adalah koefisien variabel independen yang diamati dari unit ke-i pada periode ke-t;

4. $\quad x_{i t}$ adalah nilai dari variabel independen yang diamati (vektor) dari unit ke-i pada periode ke-t;

5. $\mu_{i t}$ adalah nilai komponen error (error term) dari variabel independen unit ke-i pada periode ke-t

Atau dapat pula ditulis dengan:

$Y_{t}=\alpha+b_{1} X_{1 i t}+b_{2} X_{2 i t}+b_{3} X_{3 i t}+b_{4} X_{4 i t}+b_{5} X_{5 i t}+b_{6} X_{6 i t}+b_{7} X_{7 i t}+b_{8} X_{8 i t}+b_{9} X_{9 i t}+b_{10} X_{10 i t}+b_{11}$ $X_{11 i t}+b_{12} X_{12 i t}+b_{13} X_{13 i t}+b_{14} X_{14 i t}+\mu_{i t}$

$\mathrm{Y}_{1}=$ Variabel Dependen Luas Area Hutan di negara-negara Asia Tenggara

$a=$ intercept

$\beta_{1} \beta_{2}=$ Koefisien regressi

$\mathrm{X}_{1}=$ GDP Nominal dalam Current US\$;

$\mathrm{X}_{2}=$ GDP Per Capita Current US\$;

$\mathrm{X}_{3}=$ Income Per Capita metode Atlas Current US\$;

$\mathrm{X}_{4}=$ Pertumbuhan Ekonomi dalam prosentase (\%),

$\mathrm{X}_{5} \quad=\quad$ Foreign Direct Investment Current US\$;

$\mathrm{X}_{6}=$ Inflasi dalam prosentase (\%);

$\mathrm{X}_{7} \quad=\quad$ Human Development Index angka indeks o s.d. 1;

$\mathrm{X}_{8} \quad=$ Population (jumlah penduduk),

$\mathrm{X}_{9} \quad=\quad$ Unemployment (angka pengangguran terbuka) dalam \%,

$X_{10}=$ Government Effectiveness Index angka indeks dengan nilai -2,5 s.d. 2,5;

$X_{11}=$ Rasio Hutang Pemerintah terhadap GDP dalam prosentase (\%),

$X_{12}=$ Corruption Perception Index (CPI) angka indeks nilai o s.d. 100;

$X_{13}=$ Voice and Accountability (VA) angka indeks nilai -2,5 s.d. 2,5; dan

$\mathrm{X}_{14}=$ Control of Corruption (CC) angka indeks nilai-2,5 s.d. 2,5;

$\mathrm{X}_{15}=$ Luas Area Pertanian dan Perkebunan dalam Kilometer persegi $\left(\mathrm{Km}^{2}\right)$

Untuk memilih model dan estimator terbaik dilakukan pengujian-pengujian berupa:

1. Pengujian Redundant Fixed Effects-Likelihood Ratio untuk memilih model terbaik antara metode common pooled dan metode fixed effect dengan hipotesis:

$\mathrm{H}_{\mathrm{O}} \quad$ : Model terbaik Common Pool

$\mathrm{H}_{1} \quad$ : Model terbaik Fixed Effect

2. Pengujian Correlated Random Effect-Hausmann Test untuk memilih model terbaik antara metode fixed effect dan metode Random effect dengan hipotesis:

$\mathrm{H}_{\mathrm{O}} \quad$ : Model terbaik Random Effect

$\mathrm{H}_{1} \quad$ : Model terbaik Fixed Effect

\section{HASIL DAN PEMBAHASAN}

Pelaksanaan pembangunan ekonomi seringkali memiliki konsekwensi pada menurunnya kualitas lingkungan dan meningkatnya polusi (kerusakan lingkungan) termasuk berkurangnya luas area hutan dan meningkatnya emisi gas karbon. Perubahan luas area hutan sebagai salah satu sumber daya ekonomi 
memiliki dimensi yang sangat luas dan sangat terkait dengan berbagai aspek kehidupan yang juga berdimensi luas dan kompleks. Dalam kenyataanya, patut disayangkan bahwa untuk dapat melakukan analisis secara mendalam dan komprehensif seringkali terkendala oleh ketidakkelengkapan data, sehingga menyebabkan keterbatasan pada variabel dan aspek yang hendak diteliti. Masalah ketidaklengkapan data yang dihadapi peneliti disebabkan oleh faktor adanya selisih waktu (time-lag) dalam penyajian data publikasi atau bahkan ketidaklengkapan data. Data-data publikasi yang digunakan dalam peneltian ini dihimpun dari data yang dirilis oleh lembaga-lembaga Bank Dunia, Bank Pembangunan Asia, UNDP dan lembaga lainnya, dan seringkali tidak lengkap terisi untuk semua variabel. Untuk itu, variabel variabel yang dikaji dalam penelitian ini dilakukan dengan upaya mencari data sekunder yang lengkap sehingga mampu mencakup dan mewakili aspek aspek ekonomi, aspek tata kelola pemerintahan, aspek sosial-demografi dan aspek fisik lingkungan.

Pendekatan ini dilakukan dengan tujuan agar keterbatasan data tidak menghalangi analisis tentang perubahan luas area hutan sebagai sumber daya alam yang patut dilestarikan dengan spektrum dan dimensi yang memadai sehingga dapat menghasilkan model yang representatif dalam menemukan determinatornya beserta berbagai alternatif kebijakannya. Hasil pengujian dan analisis terhadap data setelah melalui berbagai metode dan prosedur penelitian yang memadai dapat diuraikan sebagai berikut:

\section{Spesifikasi Model}

Dengan menggunakan analisis regresi menggunakan metode common pooled, fixed effect, diperoleh data dan informasi untuk selanjutnya dilakukan pemilihan estimator terbaik, sebagaimana tabel berikut:

Tabel 1 Hasil Estimasi dan Spesifikasi Model

\begin{tabular}{|c|c|c|c|c|c|c|c|c|}
\hline \multirow{2}{*}{ No } & \multirow{2}{*}{ Variabel dan Kriteria } & \multicolumn{2}{|c|}{ Common Pooled } & \multicolumn{2}{|c|}{ Fixed Effect } & \multicolumn{2}{|c|}{ Random Effect } & \multirow{2}{*}{ Keterangan } \\
\hline & & $p$-value & Signifikansi & $p$-value & Signifikansi & $p$-value & Signifikansi & \\
\hline A. & Variabel & & & & & & & \\
\hline & Constanta & 0.0013 & $\sqrt{ }$ & 0.0006 & $\sqrt{ }$ & 0.0000 & $\sqrt{ }$ & \\
\hline & Gross Domestic Product & 0.0008 & $\sqrt{ }$ & 0.9414 & $x$ & - & - & \\
\hline & GDP Perkapita & 0.2296 & $x$ & 0.8630 & $x$ & - & - & \\
\hline & Penerimaan Perkapita & 0.0317 & $\sqrt{ }$ & 0.6264 & $x$ & - & - & \\
\hline & Pertumbuhan Ekonomi & 0.9917 & $x$ & 0.6232 & $x$ & 0.0000 & $\sqrt{ }$ & \\
\hline & Foreign Direct Investment & 0.0001 & $\sqrt{ }$ & 0.7029 & $x$ & - & - & \\
\hline & Inflasi & 0.2392 & $x$ & 0.3708 & $x$ & 0.5778 & $x$ & \\
\hline & Government Effectiveness & 0.5546 & $x$ & 0.3392 & $x$ & 0.0000 & $\sqrt{ }$ & \\
\hline & Ratio Hutang Pemerintah terhadap GDP & 0.3415 & $x$ & 0.0006 & $\sqrt{ }$ & 0.0000 & $\sqrt{ }$ & \\
\hline & Corruption Perception Index & 0.0957 & $\mathrm{x}$ & 0.0119 & $\sqrt{ }$ & 0.0000 & $\sqrt{ }$ & \\
\hline & Voice and Accountability & 0.0000 & $\sqrt{ }$ & 0.0002 & $\sqrt{ }$ & 0.0000 & $\sqrt{ }$ & \\
\hline & Control of Corruption & 0.4203 & $\mathrm{x}$ & 0.3400 & $\mathrm{X}$ & - & - & \\
\hline & Human Development Index (HDI) & 0.0000 & $\sqrt{ }$ & 0.0567 & $x$ & 0.0000 & $\sqrt{ }$ & \\
\hline & Ratio Jumlah Pengangguran Terbuka & 0.0000 & $\sqrt{ }$ & 0.8763 & $x$ & - & - & \\
\hline & Jumlah Penduduk & 0.0000 & $\sqrt{ }$ & 0.0041 & $\sqrt{ }$ & 0.0000 & $\sqrt{ }$ & \\
\hline & Luas Area Pertanian dan Perkebunan & 0.0000 & $\sqrt{ }$ & 0.0568 & $\sqrt{ }$ & 0.0000 & $\sqrt{ }$ & \\
\hline B. & Kriteria & & & & & & & \\
\hline & R-Squared & 0.9716 & Sangat kuat & 0.9998 & Sangat kuat & 0.9218 & Sangat kuat & \\
\hline & Adjusted R-Squared & 0.9650 & Sangat kuat & 0.9997 & Sangat kuat & 0.9118 & Sangat kuat & \\
\hline & Standar Error of Regression & 48359.9100 & - & 4747.4600 & - & 76764.1300 & - & \\
\hline & F-Statistic & 146.1629 & Signifikan & 9753.4780 & Signifikan & 91.7253 & Signifikan & \\
\hline & Prob (F-statistic) & 0.0000 & Signifikan & 0.0000 & Signifikan & 0.0000 & Signifikan & \\
\hline
\end{tabular}

Sumber: Data sekunder Worldbank, UNDP, ADB, Tradingeconomy dan lain-lain diolah. 
Berdasarkan data dan hasil analisis sebagaimana tabel $\mathbf{1}$ di atas, dengan memperhatikan nilai R-squared dan Adjusted R-Squared yang lebih besar maka secara common sense bahwa metode Fixed Effect lebih baik dibandingkan dengan metode Common Pooled maupun metode Random Effect. Selain dengan melihat nilai adjusted R-Squared secara common sense juga dapat dilihat dari nilai F-Statistic yang bernilai terbesar dan nilai standard error o Regression yang terkecil. Selain itu, berdasarkan hasil verifikasi dengan memperhatkan nilai $p$-value pada masing-masing variabel dan dibandingkan dengan nilai $\alpha=0,05$ dapat terlihat bahwa terdapat beberapa variabel yang tidak memiliki pengaruh yang signifikan dalam model yaitu GDP Percapita, Pertumbuhan Ekonomi (Economic Growth), Inflasi, Government Effectiveness, Ratio Hutang Pemerintah terhadap GDP, Corruption Perception Index dan Control of Corruption ( $\mathrm{COC}$ ). Lebih lanjut sebelum dilakukan beberapa pengujian untuk memilih model terbaik maka berdasarkan konfirmasi teori variabel-variabel dengan nilai p-value yang tidak signifikan tersebut dihilangkan dari model sehingga dapat ditetapkan model terbaik untuk masing-masing metode. Adapun hasil pemilihan model terbaik berdasarkan metode Common pool, Fixed Effect dan Random Effect sebagai berikut:

\section{a. Spesifikasi Model dan Estimasi Metode Common Pooled Least Squares}

Dengan berdasarkan pada variabel-variabel yang signifikan pada nilai $p$-value pada $a=0,05$ diperoleh hasil terbaik dengan menggunakan metode common pool sebagai berikut:

Tabel 2: Hasil Analisis Regresi Terbaik dengan Metode Common Pooled

\begin{tabular}{|c|c|c|c|c|c|}
\hline \multirow{2}{*}{ No } & \multirow{2}{*}{ Variabel dan Kriteria } & \multicolumn{3}{|c|}{ Common Pooled } & \multirow{2}{*}{ Keterangan } \\
\hline & & Coefficient & t-statistic & p-value & \\
\hline \multirow[t]{10}{*}{ A. } & \begin{tabular}{|l|} 
Variabel \\
Constanta
\end{tabular} & 892479.7 & 7.919706 & 0.0000 & signifikan \\
\hline & Gross Domestic Product & $4.50 E-07$ & 4.041002 & 0.0001 & signifikan \\
\hline & Income Perkapita & $-4.32 \mathrm{E}+00$ & -3.066742 & 0.0031 & signifikan \\
\hline & Foreign Direct Investment & 4.95E-06 & 4.949296 & 0.0000 & signifikan \\
\hline & Corruption Perception Index & $3.81 \mathrm{E}+03$ & 3.559566 & 0.0007 & signifikan \\
\hline & Voice and Accountability & -72452.18 & -5.099195 & 0.0000 & signifikan \\
\hline & Human Development Index & -1803407 & -9.384256 & 0.0000 & signifikan \\
\hline & Jumlah Penduduk & -0.003844 & -9.700104 & 0.0000 & signifikan \\
\hline & Ratio Pengangguran Terbuka & 88042.1 & 11.27472 & 0.0000 & signifikan \\
\hline & Luas Area Pertanian dan Perkebunan & 2.133335 & 11.80957 & 0.0000 & signifikan \\
\hline \multirow[t]{6}{*}{ B. } & Kriteria & & \multirow{6}{*}{\multicolumn{2}{|c|}{ Model Signifik }} & \\
\hline & R-Squared & 0.9695 & & & \\
\hline & Adjusted R-Squared & 0.9655 & & & \\
\hline & Standar Error of Regression & 47986.9500 & & & \\
\hline & F-Statistic & 246.8506 & & & \\
\hline & Prob (F-statistic) & 0.0000 & & & \\
\hline
\end{tabular}

Sumber: Data sekunder Worldbank, UNDP, ADB, Tradingeconomy dan lain-lain diolah.

Setelah dilakukan proses pemilihan dan spesifikasi data dengan menghilangkan variabel-variabel yang tidak signifikan dengan memperhatikan nilai t-statistic dan membandingkan nilai p-value dengan nilai $a$ = 0,05 maka dari 15 variabel yang dianalisis dengan menggunakan metode common pooled least squared terdapat 9 variabel dalam model yang signifikan dengan nilai p-value masing-masing lebih kecil dari nilai $\alpha=0,05$. Adapun variabel-variabel yang tidak signifikan terhadap luas area hutan di negaranegara kawasan Asia Tenggara yaitu: GDP Percapita, Pertumbuhan Ekonomi (Economic Growth), Inflasi, 
Government Effectiveness, Ratio Hutang Pemerintah terhadap GDP, Corruption Perception Index dan Control of Corruption ( $\mathrm{COC}$ ) dengan cara membandingkan nilai p-value yang lebih besar dari nilai 0,05. Di sisi lain dengan berkurangnya jumlah variabel-variabel yang tidak signifikan maka model secara keseluruhan tetap mampu dan signifikan untuk mengestimasi luas area hutan di kawasan Asia Tenggara yang juga menunjukan ada atau tidaknya proses deforetasi, dengan cara melihat nilai $\mathrm{F}$ Statistic dan Prob (F-statistic). Dengan nilai F-statistic 246.8506 dan Pob (F-statistic) $0,0000<0,05$ pada nilai $\alpha=0,05$. Dengan berkurangnya jumlah variabel maka nilai R-squared berkurang menjadi 0,9695 dan nilai Adjusted R-squared menjadi 0,9655 dan dapat disimoulkan bahwa dengan metode Common Pooled model dapat menjelaskan dan melakukan estimasi luas area hutan sebesar 96,55\% yang menunjukan derajat kontribusi yang sangat kuat dan sisanya sebesar 3,45\% dijelaskan oleh variabel-variabel lainnya yang tidak terdapat dalam model.

Dari hasil analisis data dengan menggunakan metode common-pooled least squares dapat dijelaskan bahwa dari aspek ekonomi terdapat variabel-variabel yang secara signifikan mempengaruhi perubahan luas area hutan di kawasan Asia Tenggara yaitu Produk Domestik Bruto dan Foreign Direct Investment dengan arah yang positif dan Income Perkapita dengan arah yang negatif (berlawanan). Hal tersebut sejalan dengan pandangan para ahli seperti (Houghton, et al., 2012) dan (Cuaresma, et al., 2016). Dari aspek tata kelola pemerintahan terdapat variabel-variabel yang secara signifikan berpengaruh terhadap luas areal hutan yaitu Corruption Perception Index (CPI) dengan arah yang positif dan Voice and Accountability dengan arah yang negatif. Temuan tersebut mengkonfirmasi penelitian (Cuaresma, et al., 2016), (Koyuncu \& Yilmaz, 2009) dan (Pachmann, 2018). Selanjutnya dari aspek sosial dan demografi angka Indeks Pembangunan Manusia dan Jumlah Penduduk berpengaruh signifikan dengan arah negative dan ratio pengangguran terbuka berpengaruh signifikan dengan arah positif terhadap perubahan luas area hutan. Temuan tersebut sejalan dengan pandangan (Dariono, Siregar, \& Nofrizal, 2018), (Sunderlin \& Resosudarmo, 1996), (Liu, 2013), (Samsuri, Jaya, Kusmana , \& Murtilaksono, 2014) dan (Imai, Furukawa, Tsujino, Kitamura, \& Yumoto, 2018). Berkaitan dengan aspek Lingkungan dan fisik terutama kegiatan pembukaan lahan hutan untuk lahan pertanian perkebunan terdapat pengaruh yang signifikan dengan arah positif terhadap perubahan luas area hutan. Hal tersebut bertentangan dengan pandangan (Rudel, 2013) dan (Houghton, et al., 2012) yang menemukan pengaruh signifikan dan arah negative antara luas area lahan pertanian dan perkebunan dengan perubahan luas area hutan. Sesuai dengan prosedur pengolahan data panel dan teoris sebagai landasan analisis selanjutnya pengolahan data panel perlu dilakukan dengan memperhatikan pengaruh cross-section atau time-series dari data dengan menggunakan metode fixed effect dan random effect untuk selanjutnya ditentukan spesifikasi model yang terbaik.

\section{b. Spesifikasi Model dan Estimasi Terbaik dengan Metode Fixed Effect dan Random Effect}

Berdasarkan pada variabel-variabel yang signifikan pada nilai $p$-value pada $\alpha=0,05$ diperoleh hasil terbaik dengan menggunakan metode fixed effect dan random effect, sebagai berikut (tabel 3).

Setelah dilakukan estimasi model dengan menggunakan metode Common Pooled dan diperoleh model dan spesifikasi terbaik dengan menghilangkan variabel-variabel yang tidak signifikan serta konfirmasi dengan teori-teori dan hasil temuan penelitian terdahulu (review literature) maka prosedur selanjutnya adalah melakukan estimasi dengan menggunakan metode Fixed Effect dan Random Effect. Berdasarkan analisis dengan menggunakan metode Fixed Effect ternyata dari 9 variabel yang signifikan menggunakan metode Common Pooled, hanya terdapat 6 variabel yang signifikan yaitu: Ratio Hutang Pemerintah terhadap GDP, Corruption Perception Index, Voice and Accountability, Human Development Index, Jumlah Penduduk dan Luas Area Pertanian dan Perkebunan. Dengan memperhatikan nilai F-Statistic 17076,5800 dan Prob (F-statistic) sebesar 
0,0000 dengan menggunakan metode Fixed Effect model secara keseluruhan valid dan signifikan dalam mengestimasi luas areal hutan di negara-negara kawasan Asia Tenggara. Dengan nilai Adjusted R-Squared bernilai 0,9997 dapat disimpulkan bahwa model Fixed Effect memiliki derajat konstribusi sebesar $\mathbf{9 9 , 9 7 \%}$ dan sisanya sebesar 0,03\% dipengaruhi oleh variabel-variabel lainnya selain 6 variabel yang secara signifikan mempengaruhi luas area hutan di kawasan Asia Tenggara.

Tabel 3. Hasil Analisis Regresi Terbaik dengan Metode fixed effect dan Random effect

\begin{tabular}{|c|c|c|c|c|c|c|c|c|}
\hline \multirow{2}{*}{ No } & \multirow{2}{*}{ Variabel dan Kriteria } & \multicolumn{3}{|c|}{ Fixed Effect } & \multicolumn{3}{|c|}{ Random Effect } & \multirow{2}{*}{ Keterangan } \\
\hline & & Coefficient & $p$-value & Signifikansi & Coefficient & p-value & Signifikansi| & \\
\hline \multirow[t]{8}{*}{ A. } & Variabel & & & & & & & \\
\hline & C & 206675.20 & 0.0000 & $\sqrt{ }$ & 236351.1 & 0.0000 & $\sqrt{ }$ & signifikan pada $\alpha=0,05$ \\
\hline & Ratio Hutang Pemerintah terhadap GDP & 585.7366 & 0.0001 & $\sqrt{ }$ & $4.80 E+02$ & 0.0015 & $\sqrt{ }$ & signifikan pada $\alpha=0,05$ \\
\hline & Corruption Perception Index & 832.9959 & 0.0006 & $\sqrt{ }$ & $5.62 \mathrm{E}+02$ & 0.0167 & $\sqrt{ }$ & signifikan pada $\alpha=0,05$ \\
\hline & Voice and Accountability & -12825.93 & 0.0001 & $\sqrt{ }$ & -9228.94 & 0.0036 & $\sqrt{ }$ & signifikan pada $\alpha=0,05$ \\
\hline & Human Development Index & 129421.40 & 0.0144 & $\sqrt{ }$ & - & - & $\mathbf{X}$ & tidak signifikan \\
\hline & Jumlah Penduduk & -0.001422 & 0.0001 & $\sqrt{ }$ & -0.001203 & 0.0011 & $\sqrt{ }$ & signifikan pada $\alpha=0,05$ \\
\hline & Luas Area Pertanian dan Perkebunan & -0.5001 & 0.0217 & $\sqrt{ }$ & - & - & $\mathbf{X}$ & tidak signifikan \\
\hline \multirow[t]{11}{*}{ B. } & Cross Section & & & & & & & \\
\hline & Indonesia & 1231788.00 & & & 965994.1 & & & \\
\hline & Singapura & -451804.80 & & & -329404.2 & & & \\
\hline & Malaysia & -83477.74 & & & -37016.63 & & & \\
\hline & Brunei & -369303.10 & & & -270718.1 & & & \\
\hline & Philipina & -76823.92 & & & -88659.06 & & & \\
\hline & Thailand & 3168.51 & & & -38024.49 & & & \\
\hline & Laos & -142826.70 & & & -96086.87 & & & \\
\hline & Cambodia & -182926.70 & & & -156316.8 & & & \\
\hline & Vietnam & -36045.76 & & & -38242.63 & & & \\
\hline & Myanmar & 108252.50 & & & 88474.68 & & & \\
\hline \multirow[t]{6}{*}{ C. } & Kriteria & & & & & & & \\
\hline & R-Squared & 0.9998 & \multicolumn{2}{|c|}{ Sangat Kuat } & 0.3661 & \multicolumn{2}{|c|}{ Lemah } & \\
\hline & Adjusted R-Squared & 0.9997 & \multicolumn{2}{|c|}{ Sangat Kuat } & 0.3323 & \multicolumn{2}{|c|}{ Lemah } & \\
\hline & Standar Error of Regression & 4538.3450 & \multicolumn{2}{|c|}{ Lebih baik/kecil } & 5826.8880 & \multicolumn{2}{|c|}{ Lebih besar } & \\
\hline & F-Statistic & 17076.5800 & \multicolumn{2}{|c|}{ Model Signifikan } & 10.8296 & \multicolumn{2}{|c|}{ Model Signifikan } & \\
\hline & Prob (F-statistic) & 0.0000 & \multicolumn{2}{|c|}{ Model Signifikan } & 0.0000 & \multicolumn{2}{|c|}{ Model Signifikan } & \\
\hline
\end{tabular}

Sumber: $\quad$ Data sekunder Worldbank, UNDP, ADB, Tradingeconomy dan lain-lain diolah.

Setelah dilakukan estimasi model dengan menggunakan metode Common Pooled dan diperoleh model dan spesifikasi terbaik dengan menghilangkan variabel-variabel yang tidak signifikan serta konfirmasi dengan teori-teori dan hasil temuan penelitian terdahulu (review literature) maka prosedur selanjutnya adalah melakukan estimasi dengan menggunakan metode Fixed Effect dan Random Effect. Berdasarkan analisis dengan menggunakan metode Fixed Effect ternyata dari 9 variabel yang signifikan menggunakan metode Common Pooled, hanya terdapat 6 variabel yang signifikan yaitu: Ratio Hutang Pemerintah terhadap GDP, Corruption Perception Index, Voice and Accountability, Human Development Index, Jumlah Penduduk dan Luas Area Pertanian dan Perkebunan. Dengan memperhatikan nilai F-Statistic 17076,5800 dan Prob (F-statistic) sebesar 0,0000 dengan menggunakan metode Fixed Effect model secara keseluruhan valid dan signifikan dalam mengestimasi luas areal hutan di negara-negara kawasan Asia Tenggara. Dengan nilai Adjusted R-Squared bernilai 0,9997 dapat disimpulkan bahwa model Fixed Effect memiliki derajat 
konstribusi sebesar $\mathbf{9 9 , 9 7 \%}$ dan sisanya sebesar 0,03\% dipengaruhi oleh variabel-variabel lainnya selain 6 variabel yang secara signifikan mempengaruhi luas area hutan di kawasan Asia Tenggara.

Selanjutnya dengan menggunakan metode Random Effect ternyata hanya terdapat 4 variabel yang signifikan dalam mengestimasi luas areal hutan di kawasan Asia Tenggara yaitu: Ratio Hutang Pemerintah terhadap GDP, Corruption Perception Index, Voice and Accountability dan Jumlah Penduduk. Dengan memperhatikan nilai F-Statistic 10,8296 dan Prob (F-statistic) sebesar 0,0000 dengan menggunakan metode Random-Effect secara keseluruhan signifikan dan dapat secara tepat dalam mengestimasi luas areal hutan di negara-negara kawasan Asia Tenggara. Dengan nilai Adjusted R-Squared sebesar 0,3323 maka dapat dijelaskan bahwa dengan metode Random Effect model secara keseluruah memiliki derajat kontribusi dalam mengestimasi varaibel luas areal hutan sebesar $33,23 \%$ dan sisanya sebesar $66,77 \%$ dijelaskan oleh variabel-variabel lainnya. Secara sederhana dari data dan informasi dalam Tabel 3 dengan memperhatikan nilai $R$-Squared dan $R$ Squared Adjusted yang lebh besar atau nilai Standar Error of Regrestion yang lebih kecil serta jumlah variabel yang signifikan berdasarkan nilai $p$-value dibandingkan dengan nilai $a=0,05$ dapat dijelaskan bahwa metode Fixed Effect lebih baik dalam mengukur perubahan luas area hutan di kawasan Asia Tenggara dibandingkan metode Random Effect. Namun, sesuai prosedur perlu dilakukan serangkaian pengujian untuk memiliki spesifikasi model yang terbaik dengan Uji Redundant dan Uji Hausmann yang akan dilakukan selanjutnya.

\section{c. Pengujian dan Pemilihan Estimator Terbaik}

Setelah dilakukan pemilihan dan spesifikasi model terbaik dengan menggunakan metode Common Pool, Fixed Effect dan Random Effect, selanjutnya dilakukan pengujian untuk memilih model terbaik dari ketiga metode yang digunakan. Adapun hasil pengujian Redundant Fixed EffectLikelihood Test dan Correlated Random Effect-Hausmann Test pada derajat keyakinan 95\% dan pvalue pad nilai $\alpha=0,05$, sebagai berikut:

Tabel 4. Hasil Pengujian dan Pemilihan Model terbaik

\begin{tabular}{|c|l|l|l|c|c|l|}
\hline No. & \multicolumn{1}{|c|}{ Pengujian } & Pemilihan Metode & \multicolumn{1}{|c|}{ Hipotesis } & $\begin{array}{l}\text { Chi-Square } \\
\text { Statistic }\end{array}$ & p-value & \multicolumn{1}{|c|}{ Keterangan } \\
\hline 1 & $\begin{array}{l}\text { Redundant Fixed Effect- } \\
\text { Likelihood Ratio Test }\end{array}$ & $\begin{array}{l}\text { Common Pool dan } \\
\text { Fixed Effect }\end{array}$ & $\begin{array}{l}\text { Ho : Common Pool Best } \\
\text { H1 : Fixed Effect Best }\end{array}$ & 467.003683 & 0.0000 & $\begin{array}{l}\text { Fixed Effect Model } \\
\text { Terbaik }\end{array}$ \\
\hline 2 & $\begin{array}{l}\text { Correlated Random Effect- } \\
\text { Hausmann Test }\end{array}$ & $\begin{array}{l}\text { Fixed Effect dan } \\
\text { Random Effect }\end{array}$ & $\begin{array}{l}\text { Ho : Random Effect Best } \\
\text { H1 : Fixed Effect Best }\end{array}$ & 41.731738 & 0.0000 & $\begin{array}{l}\text { Fixed Effect Model } \\
\text { Terbaik }\end{array}$ \\
\hline
\end{tabular}

Sumber: Data diolah.

Dengan serangkaian pengujian maka dapat disimpulkan bahwa model terabik untuk melakukan estimasi dana analisis faktor-faktor yang mempengaruhi indeks pembangunan manusia di kawasan Asia Tenggara adalah metode Fixed Effect. Hal tersebut terlihat pada nilai p-Value pada pengujian Redundant $\mathrm{FE}$-likelihood ratio bernilai 0,0000 yang lebih kecil dari nilai $\alpha=0,05$ sehingga menolak $\mathrm{H}_{0}$ atau model Fixed Effect lebih baik dibandingkan dengan metode Common Pool. Selanjutya sesuai hasil pengujian Hausmann untuk memilih metode terbaik antara Random Effect dan Fixed Effect, dapat disimpulkan bahwa model Fixed Effect lebih baik karena nilai p-value sebesar 0,0122 lebih kecil dari nilai $a=0,05$. Dapat disimpulkan pula bahwa dari ketiga model yang terbaik untuk melakukan estimasi adalah model Fixed Effect. 


\section{d. Interpretasi dan Analisis Estimator Terbaik}

Berdasarkan hasil pengujian dan pemilihan estimator terbaik maka model yang lebih tepat dalam melakukan estimasi terhadap variabel-variabel determinan bagi indeks pembangunan manusia di negara-negara ASEAN dengan menggunakan metode fixed effect. Model tersebut yang selanjutnya akan dipilih dan dilakukan interpretrasi serta analisis dalam penelitian ini, sebagai berikut:

Tabel 5. Pemilihan Model terbaik dengan Fixed Effect

\begin{tabular}{|c|c|c|c|c|}
\hline \multirow{2}{*}{ No } & \multirow{2}{*}{ Variabel dan Kriteria } & \multicolumn{2}{|c|}{ Fixed Effect } & \multirow{2}{*}{ Keterangan } \\
\hline & & Coefficient & p-value & \\
\hline \multirow[t]{8}{*}{ A. } & Variabel & & & \\
\hline & C & 206675.20 & 0.0000 & signifikan pada $\alpha=0,05$ \\
\hline & Ratio Hutang Pemerintah terhadap GDP & 585.7366 & 0.0001 & signifikan pada $\alpha=0,05$ \\
\hline & Corruption Perception Index & 832.9959 & 0.0006 & signifikan pada $\alpha=0,05$ \\
\hline & Voice and Accountability & -12825.93 & 0.0001 & signifikan pada $\alpha=0,05$ \\
\hline & Human Development Index & 129421.40 & 0.0144 & signifikan pada $\alpha=0,05$ \\
\hline & Jumlah Penduduk & -0.001422 & 0.0001 & signifikan pada $\alpha=0,05$ \\
\hline & Luas Area Pertanian dan Perkebunan & -0.5001 & 0.0217 & signifikan pada $\alpha=0,05$ \\
\hline \multirow[t]{11}{*}{ B. } & Cross Section & & & \\
\hline & Indonesia & 1231788.00 & & \\
\hline & Singapura & -451804.80 & & \\
\hline & Malaysia & -83477.74 & & \\
\hline & Brunei & -369303.10 & & \\
\hline & Philipina & -76823.92 & & \\
\hline & Thailand & 3168.51 & & \\
\hline & Laos & -142826.70 & & \\
\hline & Cambodia & -182926.70 & & \\
\hline & Vietnam & -36045.76 & & \\
\hline & Myanmar & 108252.50 & & \\
\hline \multirow[t]{6}{*}{ C. } & Kriteria & & & \\
\hline & R-Squared & 0.9998 & & Sangat Kuat \\
\hline & Adjusted R-Squared & 0.9997 & & Sangat Kuat \\
\hline & Standar Error of Regression & 4538.3450 & & ebih baik/kecil \\
\hline & F-Statistic & 17076.5800 & & lodel Signifikan \\
\hline & Prob (F-statistic) & 0.0000 & & lodel Signifikan \\
\hline
\end{tabular}

Sumber: Data diolah.

Sebagaimana data pada tabel 5 di atas dapat disimpulkan bahwa dengan tingkat signifikansi < dari nilai $\alpha=0,05$ maka dari 15 variabel GDP, GDP Percapita, Income Perkapita, Pertumbuhan Ekonomi, Foreign Direct Investment, Inflasi, Government Effectiveness, Ratio Hutang Pemerintah terhadap GDP, Corruption Perception Index, Voice and Accountability, Control of Corruption, Human Development Index, Penduduk, Ratio Tingkat Pengangguran dan Luas Area Pertanian dan Perkebunan terdapat 6 (enam) variabel yang signifikan yaitu: $\mathrm{HDI}\left(\mathbf{X}_{7}\right)$, Jumlah Penduduk $\left(\mathbf{X}_{8}\right)$, Ratio Hutang Pemerintah Terhadap GDP $\left(\mathbf{X}_{11}\right), \operatorname{CPI}\left(\mathbf{X}_{12}\right)$, VA $\left(\mathbf{X}_{13}\right)$, dan Luas Area Pertanian dan Perkebunan $\left(\mathbf{X}_{15}\right)$.

Berdasarkan hasil regresi data panel dengan metode fixed effect pada angka 1 maka dapat dilakukan penulisan persamaan sebagai berikut:

$$
Y=206675,20+129421,40 X_{7}-0,001422 X_{8}+585,7366 X_{11}+832,9959 X_{12}-12825,93 X_{13}-0,5001 X_{15}
$$

Dengan nilai konstanta sebesar 206.675,20 dapat disimpulkan bahwa rerata luas areal hutan di negara-negara di kawasan Asia Tenggara sebesar 206.675,20 kilometer persegi. Selanjutnya dapat disimpulkan pula bahwa Ratio Hutang pemerintah terhadap GDP, Human Developmet Index dan Corruption Perception Index memiliki pengaruh yang signifikan dengan arah positif terhadap Luas Area Hutan di negara-negara kawasan Asia Tenggara. Dari data dalam tabel 5 dapat dijelaskan pula bahwa jika terjadi kenaikan nilai ratio hutang Pemerintah terhadap GDP sebesar $1 \%$ maka luas area hutan di negara-negara di 
kawasan Asia Tenggara akan naik sebesar 585,74 kilometer persegi. Demikian halnya dengan nilai Indeks Pembangunan Manusia yang mencerminkan aspek kualitas sumber daya manusia, apabila naik sebesar 0,01 point maka luas area hutan di negara-negara di kawasan Asia Tenggara akan meningkat sebesar 1.294,21 kilometer persegi. Kondisi yang sama terjadi pada angka Corruption Perception Index, apabila CPI naik sebesar 1 point dari rentang 0-100, maka luas areal hutan di kawasan Asia Tenggara akan meningkat sebesar 833 kilometer persegi.

Sebaliknya nilai indeks keterbukaan dan akuntabilitas (voice and accountability), jumlah penduduk dan luas area pertanian dan kehutanan memiliki pengaruh yang signifikan dan berarah negatif terhadap luas area hutan di kawasan Asia Tenggara. Dapat disimpulkan bahwa jika variabel-variabel voice and accountability, jumlah penduduk dan luas area pertanian dan perkebunan meningkat maka luas area hutan akan berkurang, demikian pula sebaliknya. Variabel keterbukaan dan akuntabilitas yang menandakan kondisi dan iklim keterbukaan dan demokrasi untuk menyampaikan aspirasi dan akuntabilitas berpengaruh signifikan dan negatif terhadap luas area hutan di kawasan Asia Tenggara. Apabila angka indeks voice and accountability naik 1 point dari rentang indeks -2,5 sampai 2,5 maka luas area hutan di kawasan Asia Tenggara akan berkurang sebesar 12.825,93 kilometer persegi. Hal yang sama terjadi apabila jumlah penduduk bertambah sebesar 1 orang maka luas are hutan kawasan Asia Tenggara akan berkurang sebesar 0,001422 kilometer persegi. Dapat diinterpretasikan pula bahwa jika jumlah penduduk di kawasan Asia Tenggara bertambah sebanyak 1.000 jiwa maka luas area hutan akan berkurang sebesar 1,42 kilometer persegi. Hubungan antara luas area hutan dengan luas lahan pertanian dan perkebunan menandakan terjadinya trade-off atau hubungan substitusi, jika luas area pertanian dan perkebunan meningkat maka akan semakin mengurangi luas lahan hutan. Apabila luas area pertanian dan perkebunan meningkat sebesar 1 kilometer persegi, maka luas area hutan negara-negara di kawasan Asia Tenggara akan berkurang sebesar 0,50 kilometer persegi. Dapat diartikan pula jika terjadi penambahan dan perluasan lahan perkebunan dan pertanian di kawasan Asia Tenggara dapat dipastikan bahwa $50 \%$ dari perluasan lahan tersebut berasal dari penebangan atau pembukaan area hutan (deforestasi).

Dengan nilai F-Statistic sebesar 17076,58 dan nilai $p$-value $0,0000<0,05$ pada $a=0,05$ dapat disimpulkan bahwa model dengan persamaan $Y=206675,20+129421,40 X_{7}-0,001422 X_{8}+585,7366 X_{11}+$ 832,9959 $X_{12} \quad-12825,93 X_{13}-0,5001 X_{15}$ signifikan dan mampu secara tepat dalam melakukan estimasi terhadap kondisi dan luas area hutan atau proses deforestasi pada negara-negara di kawasan Asia Tenggara pada periode 2008-2015. Selanjutnya dengan nilai R-Squared sebesar 0,9998 maka dapat disimpulkan bahwa model dapat secara tepat mengestimasi hubungan antar variabel dalam model terhadap proses deforestasi atau luas area hutan negara-negara di kawasan Asia Tenggara sebesar 99,98\% sedangkan $0,02 \%$ dijelaskan oleh variabel-variabel lainnya yang tidak terdapat dalam model atau variabelvariabel selain Human Development Index $\left(\mathbf{X}_{7}\right)$, Jumlah Penduduk $\left(\mathbf{X}_{8}\right)$, Ratio Hutang Pemerintah Terhadap $\operatorname{GDP}\left(\mathbf{X}_{11}\right)$, Corruption Perception Index $\left(\mathbf{X}_{12}\right)$, Voice and Accountability $\left(\mathbf{X}_{13}\right)$, dan Luas Area Pertanian dan Perkebunan $\left(\mathbf{X}_{15}\right)$.

\section{Diskusi dan Alternatif Kebijakan}

Sesuai hasil analisis dan pengolahan data serta memperhatikan informasi yang dihasilkan dalam interpretasi data dapat dijelaskan bahwa model terbaik untuk melakukan estimasi terhadap perubaham luas area hutan di kawasan hutan dengan menggunakan metode fixed effect. Variabel-variabel yang secara signifikan mendorong peningkatan luas area hutan dan di sisi lain menghambat berkurangnya area hutan (deforestasi dan degradasi hutan), dengan derajat kontribusi yang terbesar hingga terkecil secara berturut-turut adalah: Human Development Index, Corruption Perception Index dan Ratio Hutang Pemerintah Terhadap GDP. Hal tersebut menandakan bahwa upaya untuk mencegah terjadinya penggundulan hutan dan perubahan fungsi hutan adalah dengan mendorong peningkatan kualitas pembangunan manusia dan meningkatkan kualitas tata kelola pemerintahan yang baik. Angka Indeks 
Pembangunan Manusia yang mencerminkan aspek kualitas sumber daya manusia menjadi variabel determinan terbesar dengan arah yang positif, dan dapat disimpulkan apabila IPM naik sebesar 0,01 point maka luas area hutan di negara-negara di kawasan Asia Tenggara akan meningkat sebesar 1.294,21 kilometer persegi. Hal tersebut menjelaskan teori bahwa upaya meningkatkan keunggulan kompetetitif salah satunya melalui pembangunan aspek sumber daya manusia akan meningkatkan keunggulan komparatif berupa terjaganya sumber daya alam salah satunya sumber daya hutan. Hal tersebut sejalan dengan konsep pembangunan berkelanjutan sebagaimana dikemukakan para ahli yang menitikberatkan pada faktor manusia seperti: (Sen, 1999), (Anand \& Sen, 1997) dan (Ul-Haq, 2003) serta (Todaro \& Smith, 2006).

Selain meningkatkan kualitas sumber daya manusia, langkah selanjutnya yang dapat dilakukan untuk meningkatkan luas area hutan adalah dengan meningkatkan tata kelola pemerintahan salah satunya mencegah terjadinya peluang korupsi dalam pemberian izin pengelolaan hutan, penegakan hukum dan indikator-indikator lainnya yang sejalan dengan indeks persepsi korupsi. Hal tersebut sejalan dengan temuan (Cuaresma, et al., 2016), (Koyuncu \& Yilmaz, 2009) dan (Pachmann, 2018). Variabel CPI memiliki pengaruh yang signifikan untuk mencegah terjadinya deforestasi dan degradasi luas area hutan di kawasan Asia Tenggara. Salah satu temuan yang cukup menarik adalah pengaruh dari ratio hutang Pemerintah terhadap GDP bagi perubahan luas area hutan. Dengan arah yang positif dan nilai $1 \%$ peningkatan ratio hutang pemerintah akan mendorong meningkatnya luas area hutan seluas 585,74 kilometer persegi. Hal ini menandakan bahwa selain hutan sebagai salah satu sumber devisa dan pembiayaan pemerintah ternyata di sisi lain memiliki hubungan positif dengan ratio hutang pemerintah. Dapat diartikan pula bahwa perubahan luas area hutan yang meningkat sejalan dengan meningkatnya ratio hutang pemerintah, sangat dimungkinkan dengan adanya komitmen negara-negara pendonor untuk memberikan hutang dan bantuan dengan kompensasi adanya upaya konservasi terhadap lingkungan salah satunya hutan. Alternatif yang dapat dilakukan dalam upaya meningkatkan perluasan area hutan agar terhindar dari deforestasi dan degradasi adalah dengan memasukan ketentuan dan jaminan negara-negara kreditur di kawasan Asia Tenggara untuk melakukan upaya pemeliharaan hutan sebagai salah satu sumber oksigen dan penangkal emisi CO2. Langkah tersebut sejalan dengan komitmen dalam United Nations Framework Convention on Climate Change (UNFCCC), kesepakatan sebagaimana tercantum dalam Protokol Kyoto (1997 dan 2005) serta REDD+ (Reducing Emissions from Deforestation and forest Degradation), sekaligus menandakan bahwa hutan masih menjadi salah satu sumber pembiayaan bagi penyelenggaraan Pemerintahan di kawasan Asia Tenggara.

Dalam penelitian ini juga ditemukan variabel-variabel yang berpengaruh signifikan namun berarah negatif bagi perubahan luas area hutan. Variabel yang terbesar dalam mendorong berkurangnya luas area hutan adalah luas area pertanian dan perkebunan. Temuan tersebut sejalan dengan hasi-hasil penelitian (Margono, et al., 2012), (Houghton, et al., 2012), (Rijal, Jaya, Tiryana, \& Saleh, 2016) dan (Rudel, 2013). Sesuai data dan informasi hasil analisis bahwa setiap pembukaan lahan pertanian dan perkebunan baru seluas 1 kilometer persegi akan mengurangi luas area hutan sebesar 0,5001 kilometer persegi. Langkah dan alternatif kebijakan adalah dengan meningkatkan upaya intensifikasi lahan dan teknologi pertanian dan di sisi lain mengurangi ektensifikasi salah satunya dengan menetapkan peraturan dan kebijakan yang ketat sehingga area hutan tidak semakin berkurang, misalnya pemberian sanksi yang berat dan tegas terhadap pembukaan lahan pertanian secara liar dan pembakaran hutan. Sejalan dengan temuan para peneliti terdahulu seperti (Dariono, Siregar, \& Nofrizal, 2018), (Sunderlin \& Resosudarmo, 1996) dan (Samsuri, Jaya, Kusmana , \& Murtilaksono, 2014) dan temuan terbaru dari (Imai, Furukawa, Tsujino, Kitamura, \& Yumoto, 2018), penelitian ini juga menemukan pengaruh yang signifikan dengan arah negative dari peningkatan jumlah penduduk. Dengan peningkatan penduduk sebesar $\mathbf{1 . 0 0 0}$ orang maka akan membuka area hutan kawasan Asia Tenggara seluas 1,42 kilometer persegi untuk mendukung kebutuhan hidup. Maka upaya dan alternatif kebijakan yang dapat dilakukan selain dengan mendorong program pembatasan 
jumlah penduduk sebagaimana keluarga berencana juga dilakukan dengan serangkaian kebijakan penegakan hukum.

Salah satu temuan yang relative baru dan layak untuk dijadikan sebagai bahan diskusi selanjutnya adalah pengaruh variabel voice and accountability yang signifikan namun berarah negatif terhadap perubahan luas area hutan. Setiap peningkatan angka indek Voice and Accountability sebesar 1 point dari interval indek -2,5 s.d. 2,5 akan mendorong berkurangnya lahan hutan di kawasan Asia Tenggara sebesar 12.825,93 kilometer persegi. Dapat diartikan pula bahwa jika angka Voice and Accountability berubah sebesar 0,01 point atau 1\% maka luas area hutan akan berkurang sebesar 128,26 kilometer persegi. Meningkatnya iklim keterbukaan, demokratisasi, kebebasan berpendapat kemungkinan menjadi pendorong penduduk atau warga negara di kawasan Asia Tenggara untuk mengekploitasi hutan secara tidak bijaksana. Alternatif kebijakan yang dapat dilakukan antara lain penegakan hukum, diseminasi dan sosialisasi akan pentingnya konsep pembangunan berkelanjutan dan upaya peningkatan kualitas sumber daya manusia sebagai subyek penentu pembangunan. Untuk itu, upaya kajian yang lebih mendalam terhadap variabel Voice and Accountability beserta indikator dan sub-sub indikatornya dapat menjadi bahan kajian bagi penelitian selanjutnya.

\section{KESIMPULAN}

Penelitian yang bertujuan menganalisis variabel-variabel yang berkaitan dengan aspek ekonomi, tata kelola pemerintahan, sosial dan demografi serta aspek fisik dan lingkungan sebagai determinan bagi peruahan luas area hutan menemukan bahwa dengan data panel pada 10 negara di kawasan Asia Tenggara dengan data time-series selama 8 (delapan) tahun mulai 2008-2015 bahwa model yang terbaik menggunakan metode Fixed Effect. Dengan melihat hasil estimasi dan spesifikasi model yang terbaik diperoleh persamaan sebagai berikut: $Y=\mathbf{2 0 6 6 7 5 , 2 0}+\mathbf{1 2 9 4 2 1 , 4 0} X_{7}$ $0,001422 X_{8}+585,7366 X_{11}+832,9959 X_{12}-12825,93 X_{13}-0,5001 X_{15}$. Dari persamaan tersebut dapat dijelaskan bahwa rerata luas areal hutan di negara-negara kawasan Asia Tenggara seluas 206.675,20 kilometer persegi, sehingga dapat dikelompokan negara-negara dengan luas area hutan yang relatif masih besar dan negara-negara yang luas arealnya relatif rendah dengan membandingkan luas areal hutan secara faktual dengan rerata luas area hutan. Penelitian ini juga menemukan bahwa dari 15 variabel yang diteliti terdapat 6 (enam) variabel yang signifikan mendorong perubahan luas areal hutan dan potensi deforestasi. Variabel-variabel tersebut adalah: Human Development Index $\left(\mathbf{X}_{7}\right)$, Jumlah Penduduk $\left(\mathbf{X}_{8}\right)$, Ratio Hutang Pemerintah Terhadap GDP $\left(\mathbf{X}_{11}\right)$, Corruption Perception Index $\left(\mathbf{X}_{12}\right)$, Voice and Accountability $\left(\mathbf{X}_{13}\right)$, dan Luas Area Pertanian dan Perkebunan $\left(\mathbf{X}_{15}\right)$. Dari persamaaan tersebut juga dapat disimpulkan bahwa terdapat 3 (tiga) variabel yang berpengarh siginifikan dan berarah positif yaitu: Human Development Index $\left(\mathbf{X}_{7}\right)$, Ratio Hutang Pemerintah Terhadap GDP $\left(\mathbf{X}_{11}\right)$, Corruption Perception Index $\left(\mathbf{X}_{12}\right)$. Hubungan dan arah yang bersifat positif tersebut menandakan bahwa apabila variabel Human Development Index, Ratio Hutang Pemerintah Terhadap GDP, Corruption Perception Index meningkat maka luas areal hutan di negara-negara Aisa Tenggara akan meningkat sehingga upaya untuk mencegah terjadinya deforestasi harus dilakukan dengan meningkatkan ketiga variabel tersebut, demikian sebaliknya. Selain tiga variabel sebagaimana disebutkan di atas, penelitian ini juga menemukan 3 (tiga) variabel yang berpengaruh signifikan terhadap perubahan luas area hutan di kawasan Asia Tenggara namun berarah negatif. Dapat diartikan bahwa apabila terjadi peningkatan variabel-variabel tersebut akan mendorong berkurangnya luas area hutan atau mendorong proses deforestasi. Sebaliknya apabila variabel- 
variabel tersebut turun maka luas area hutan akan meningkat dan deforestasi dapat dicegah. Variabel-variabel determinan dengan arah negatif terhadap perubahan luas area hutan antara lain: Luas are pertanian dan perkebunan, jumlah penduduk dan indeks Voice and Accountability. Penelitian ini juga menemukan bahwa model secara keseluruhan memiliki tingkat siginifikansi yang sangat tinggi dengan nilai Adjusted R-Squared bernilai 0,9997 dapat disimpulkan bahwa model mampu menjelaskan dan mengestimasi luas areal hutan dan proses deforestasi sebesar 99,97\% sedangkan 0,03\% dipengaruhi oleh variabel-variabel lainnya.

\section{REFERENSI}

Anand, S., \& Sen, A. (1997). Concepts of Human Development and Poverty: A Multidimensional Perspective . Human Development Papers , 1-20.

Arsyad, L. (1999). Konsep dan Pengukuran Pembangunan Ekonomi. Jakarta: Universitas Terbuka.

Carr, D. (2009). Population and deforestation: why rural migration matters. Progress in Human Geography, 33(3), 355-378. doi:https://doi.org/10.1177/0309132508096031

Cuaresma, J. C., Danylo, O., Fritz, S., McCallum, I., Obersteiner, M., \& See, L. (2016). Economic Development and forest cover: Evidence from satellite data. Vienna: Departement of Economics.

Dariono, D., Siregar, Y. I., \& Nofrizal, N. (2018). Analisis Spasial Deforestasi dan Degradasi Hutan di Suaka Margasatwa Kerumutan Provinsi Riau. Dinamika Lingkungan Indonesia, 5 Nomor 1, 27-33.

Ekananda, M. (2016). Analisis Ekonometrika Data Panel, Teori Lengkap dan Pembahasan Menyeluruh bagi Penelitian Ekonomi, Bisnis dan Sosial. Jakarta: Mitra Wacana Media.

Goncalves da Silva, H., \& Krisztina, K. J. (2010). A Service of zbw Leibniz-Informationszentrum Wirtschaft Leibniz Information Centre for Economics, Economic Causes of Deforestation in the Brazilian Amazon: A Panel Data Analysis for 2000s Retrieved from www.econstor.eu. Econstor.

Gujarati, D. (1997). Basic Econometrics Cetakan Kelima. Jakarta: Penerbit Erlangga.

Houghton, R., House, J., Pongratz, J., Van der Werf, G., DeFries, S., Hansen, M., . . Ramankutty, N. (2012). Carbon Emissions from Land Use and land-cover change. Biogeosciences, 5125-5142.

Imai, N., Furukawa, T., Tsujino, R., Kitamura, S., \& Yumoto, T. (2018). Factors affecting forest area change in southeast Asia during 1980-2010. PLoS ONE.

James Baker, D. (2014). From Kyoto to Paris: Growing Recognition of The Role of Tropical Forest area change in Climate Change HISTORY OF DEFORESTATION AND INTERNATIONAL EFFORTS. Seton Hall Journal of Diplomacy and International Relations.

Jinghan, M. (2007). Ekonomi Perencanaan dan Pembangunan . Jakarta: PT. Raja Grafindo Persada.

Koyuncu, C., \& Yilmaz, R. (2009). The Impact of Corruption on Deforestation: A Cross-Country Evidence. The Journal of Developing Areas, 42(2), 213-222., 42, 213-222.

Liu, J. (2013, December 19). Forest Sustainability in China and Implication for a Telecupied World. Asia and the Pacific Policy Studies, 230-250. doi:https://doi.org/10.1002/app5.17

Mankiw, N. (2009). Brief Principles of Macroeconomics. South-Western Cengage Lerning, Mason, USA: Cengage Learning.

Margono, B., Turubanova, S., Zhuravleva, I., Potapov, P., Tyukaniva, A., Boccini, A., . . . Hansec, M. (2012). Mapping and Monitoring deforestation and forest degradationin Sumatera (Indonesia) usig Landsat time series data sets from 1990 to 2010. Environmental Research Letter Journal, 7(3), 1-17.

Mauro, P. (1995). Corruption and Growth. The Quarterly Journal of economic, Oxford Academy, 110(1 August 1995), 681-712.

Nachrowi, D. N., \& Usman, H. (2006). Pendekatan Populer dan Praktis Ekonometrika untuk Analisis Ekonomi dan Data Keuangan. Jakarta: Lembaga Penerbit Fakultas Ekonomi Universitas Indonesia.

Nasikun. (2002). Penanggulangan Kemiskinan: Kebijakan dalam Perspektif Pergerakan Sosial. Jurnal IImu Sosial dan Ilmu Politik, 6 No. 1(Juli 2002), 1-16. 
Nawir, A. A., Murniati, \& Rumboko, L. (2007). Forest rehabilitation in Indonesia: where to after three decades? Bogor: Center for International Forestry Research (CIFOR).

Nurkse, R. (1971). The Theory of Development and The Idea of Balance Growth In: Mountjoy A.B. (eds) Developing the Underdeveloped Countries. Geographical Readings. Palgrave Macmillan. London: Palgrave Macmillan.

Pachmann, A. (2018). Corruption and Deforestation in Indonesia. Regionnal Formation and Devlopment Studies, 57-64.

Peilin Li, \& Haiying Ma. (2015). An Empirical Analysis of Economic Development in Northwest China: Based on the Vicious Circle of Poverty Demands Theory. International Journal of Business Administration, 6 no. 4(July 2015), 57-63.

Rijal, S., Jaya, I. N., Tiryana, T., \& Saleh, B. (2016). Spatial Metrics of Deforestation in Kampar and Indragiri Hulu, Riau Province. Jurnal Manajemen Hutan Tropika, 24-34.

Rosadi, D. (2012 ). Ekonometrika dan Analisis Runtun Waktu Terapan dengan Eviews. Yogyakarta: Penerbit ANDI Yogyakarta.

Rudel, T. (2013). Determinants of deforestation in sub-Saharan. Philosophical Transactions of The Royal Society $B, 1-7$.

Samsuri, Jaya, I., Kusmana , C., \& Murtilaksono, K. (2014). Analysis of Tropical Forest Landscape Fragmentation in Batang Toru Watershed, North Sumatra. Jurnal Manajemen Hutan Tropika, XX (2), 77-85.

Saputro, D. S., Demu, K. R., \& Widyaningsih, P. (2018). Nonparametric truncated spline regression model on the data of human development index (HDI) in Indonesia. 2nd International Conference on Statistics, Mathematics, Teaching, and Research (hal. 1-4). Journal of Physics: Conference Series.

Sen, A. (1999). Development as Freedom. New York: Oxford University Press.

Song X-P, Huang, C., Saatchi, S., Hansen, M., \& Townshend, J. (2015). Annual Carbon Emissions from Deforestation in the Amazon Basin between 2000 and 2010. PLOSONE, 1-21.

Sunderlin, W. D., \& Resosudarmo, I. P. (1996, December). Rates and Causes of Deforestation in Indonesia: Towards a Resolution of the Ambiguities. Occasional Paper No. 9, hal. 1-22.

Todaro, M., \& Smith, S. (2006). Economic Development Ninth Edition. United Kingdom: Pearson Education Limited.

Ul-Haq, M. (2003). The Birth of Human Development Index. Oxford, UK: Oxford University Press.

WHO. (2005). Adressing Poverty in TB Control: Options for National TB Control Programmes. World Health Organization.

Yani, N. (2016). Model Spasial deforestasi Berdasarkan Aspek Sosial di Sulawesi Selatan dan Sulawesi Barat Periode 1990-2016. Makasar: Universitas Hasanudin. 